\title{
Genes for Adult-Plant Resistance to Leaf Rust in Soft Red Winter Wheat
}

\author{
Yeshi A. Wamishe and Eugene A. Milus, Department of Plant Pathology, University of Arkansas, Fayetteville 72701
}

\begin{abstract}
Wamishe, Y. A., and Milus, E. A. 2004. Genes for adult-plant resistance to leaf rust in soft red winter wheat. Plant Dis. 88:1107-1114.
\end{abstract}

Host plant resistance in wheat (Triticum aestivum) has been the principal means of managing leaf rust caused by Puccinia triticina. The need for durable resistance has changed the focus from the use of seedling resistance to adult-plant resistance. The objectives of this study were to determine the genetic basis for adult-plant resistance and to determine the most effective method to identify adult-plant resistance genes $\operatorname{Lr} 12,13$, and 34 among 116 contemporary soft red winter wheat cultivars and breeding lines. Adult-plant resistance was detected by inoculating flag leaves with a race that was virulent on seedlings. Approximately $90 \%$ of the lines expressed resistance under controlled conditions. It was postulated that the adult-plant resistance in 67 lines was due in part to either $\operatorname{Lr} 12,13$, or 34; the adult-plant resistance detected in 17 lines was attributed to $\operatorname{Lr} 12$ based on a distinctive low infection type very similar to that on the isoline TcLr12; the adult-plant resistance in 27 lines was attributed to Lr34, as all of these lines expressed a "leaf tip necrosis" in the field (a phenotype controlled by a gene known to be tightly linked with $L r 34$ ); and the adult-plant resistance in 23 lines was attributed to $\operatorname{Lr} 13$ based on a high infection type at $18.1^{\circ} \mathrm{C}$ and low infection type at $25.5^{\circ} \mathrm{C}$ with one or more pathogen isolates that were virulent on $\operatorname{Lr} 13$ at $18.1^{\circ} \mathrm{C}$ and avirulent on $\operatorname{Lr} 13$ at $25.5^{\circ} \mathrm{C}$. The adult-plant resistance detected in the remaining $40 \%$ of the lines was due to one or more unidentified genes for adult-plant resistance. In a 4-year field study at several locations, nearly $29 \%$ of the lines were resistant at all locations, no line was susceptible at all locations, and only $30 \%$ of the lines were susceptible at one or more locations. Given that many of the lines in this study were resistant to all known races of $P$. triticina before being released as cultivars, the high frequency of adultplant resistance in this study demonstrates that adult-plant resistance can be incorporated even in the presence of highly effective seedling resistance.

Soft red winter wheat (Triticum aestivum L.) is grown in the eastern United States where the environment is often favorable for the development of leaf rust caused by Puccinia triticina Eriks. (Syn.: Puccinia recondita Rob. ex. Desm. f. sp. tritici). Use of resistant cultivars has been the principal and most economical means of managing leaf rust. Wheat lines susceptible to a given race at the seedling stage but resistant to that race at the adult stage are considered to have adult-plant resistance $(1,2)$. Some genes for adult-plant resistance have been associated with slow rusting (33) and partial resistance (29) and may have the potential to provide durable leaf rust resistance $(8,26)$.

Genes $\operatorname{Lr} 12,13$, and 34 are the most likely designated genes providing adultplant resistance to leaf rust in North America (26). Lrl2 has been used widely in North America and is expressed on leaves of adult plants as infection types $; 1$ or 2 with prominent necrosis (21). Virulence to Lr12 has been common in North America

Corresponding author: Eugene A. Milus

E-mail: gmilus@uark.edu

Accepted for publication 26 May 2004.

Publication no. D-2004-0809-01R

(C) 2004 The American Phytopathological Society
(17,20,33), and therefore, $\operatorname{Lr} 12$ alone is not likely to provide adequate resistance.

Gene Lrl3 was initially described as being expressed only in the adult stage (11); however, Dyck and Johnson (7) detected Lrl3 at the seedling stage and observed increased resistance with increasing temperature. Pretorius et al. (25) detected $\mathrm{Lr} 13$ in seedlings at $25.5^{\circ} \mathrm{C}$ but not at $18.1^{\circ} \mathrm{C}$ when inoculated with specific isolates. Low infection type for $\mathrm{Lrl3}$ was reported as ; 1 through $\mathrm{X}$ to 3 on seedlings depending on factors such as pathogen race, environmental conditions, and background genotype (21). Virulence to Lrl3 was common after wheat cultivars with $\mathrm{Lr} 13$ were grown in North America (16), and Lrl3 alone is not likely to provide an adequate level of resistance $(16,26)$. Lrl3 is tightly linked with $N e 2 m$, a gene for progressive hybrid necrosis (31). Most wheat lines with $N e 2 m$ have $\mathrm{Lrl3}$, and all lines with $L r 13$ appear to have $N e 2 m$ (21). The presence of $\mathrm{Lrl3}$ in wheat lines was postulated by crossing lines with the Australian spring wheat cultivar Spica that was known to have $\mathrm{Nel}$, the complementary gene for progressive hybrid necrosis $(31,37)$. If $F_{1}$ plants from a cross between a test line and Spica showed progressive hybrid necrosis, then the test line was determined to have $\operatorname{Lrl3}$.

Gene Lr34 has been shown to condition slow-rusting resistance $(33,36)$, partial resistance (29), and durable resistance (15) to leaf rust. Gene Lr34 was only partially effective by itself, and moderate to high levels of leaf rust infection can occur on cultivars with $\operatorname{Lr} 34$ alone $(16,19,37)$. Detecting $\operatorname{Lr} 34$ at the seedling stage has been difficult because of a high degree of variability in expression (9). Expression of Lr34 increased as plant maturity progressed (33) and as temperature and light intensity decreased $(5,10,21,33)$. Dyck (5) suggested testing for $\operatorname{Lr} 34$ at $10^{\circ} \mathrm{C}$. The gene for leaf tip necrosis $(L t n)$ is tightly linked with $L r 34$, and the presence of Lr34 was almost certain in lines that showed leaf tip necrosis (31). Leaf tip necrosis has been used as a marker to detect $L r 34$ in the adult stage $(6,33)$. However, detecting leaf tip necrosis can be obscured by genetic backgrounds (32) and variable influences of environments (6). Therefore, wheat lines that do not show leaf tip necrosis in some environments may still carry Lr34 (32). A combination of leaf tip necrosis, temperature-sensitive seedling reaction, and slow rusting in the field were collectively a good indication for the presence of Lr34 (31).

Highly effective adult-plant resistance to leaf rust was ascribed to an " $L r 34$ complex" that was considered to be the product of additive interaction among Lr34 and two or three undesignated genes for slow rusting $(10,30,34,35,37)$. The interactive effect of Lr34 with adult-plant and/or seedling resistance genes to enhance leaf rust resistance has been widely documented $(14,16,19,34)$. The combination of Lr34 with other genes has been hypothesized as the basis for durable resistance in some cultivars $(6,26)$.

In addition to the three designated adultplant resistance genes described above, there are numerous reports of unnamed genes that confer adult-plant resistance to leaf rust. The high level of adult-plant resistance in cultivar Era was reported to involve the interaction of $\mathrm{Lrl3}$ with $\mathrm{Lr} 34$ and another unidentified adult-plant resistance gene $(13,24)$. Two or three additive genes in addition to $L r 34$ were reported to be in Frontana $(33,34)$. Three accessions of Spelt wheat indicated the presence of uncharacterized adult-plant resistance genes (12). Two or more unidentified genes for slow rusting were proposed in Ciano 79 and Papago 86 (34). Several unidentified genes contributed to prolong the latent period in the line BH1146 (3).

There is little information on adult-plant resistance for leaf rust in contemporary soft red winter wheat cultivars and breed- 
ing lines. The objectives of this research were to determine the genetic basis for adult-plant resistance among 116 contemporary cultivars and breeding lines and to determine the most effective method to identify genes $\operatorname{Lr} 12,13$, and 34 .

\section{MATERIALS AND METHODS}

Wheat lines. The 116 cultivars and breeding lines from the 1998-99 Arkansas Wheat Cultivar Performance Test and the Uniform Eastern and Southern Soft Red Winter Wheat Nurseries were selected as representative of contemporary soft red winter wheat lines. These lines have been characterized for race-specific seedling resistance in a previous study (39).

Field studies. To determine field reactions to leaf rust and expression of leaf tip necrosis, the 116 lines were planted at multiple locations in Arkansas each year from 1999 to 2002. In 1999 to 2001, the lines were planted at Rohwer (Southeast Branch Station), Kibler (Vegetable Substation), and Keiser (Northeast Research and Extension Center). In 2002, they were planted at Kibler and Marianna (Cotton Branch Station). Depending on the year and location, individual plot size varied from a single row $1 \mathrm{~m}$ long to nine rows $1.8 \mathrm{~m}$ long, and the number of replications varied from two to four.

To enhance the development of leaf rust epidemics, all field experiments at Kibler were irrigated, and experiments at Kibler in 2001 and 2002 were artificially inoculated. In 2001, experiments were inoculated separately with races MCRN (a race selected to overcome Lr26) and TNRL (a common race in Arkansas during this time). In 2002, the experiment was inoculated with race TNRL. All other experiments relied on natural inoculum and were not irrigated. Race designations were as described previously (39).

To determine field reaction to leaf rust, rust intensity (percentage of foliage with symptoms) and host response (infection type) $(28,38)$ were estimated visually during soft dough stage. Rust intensity percentages (and their ranges) that were recorded were 0,2 (trace to 4 ), 7 (5 to 10 ), 15 (11 to 20 ), 30 (21 to 40 ), 50 (40 to 60 ), 70 (61 to 80$), 85$ (81 to 90$), 93$ (91 to 96 ), and 98 (>96). Rust intensity and host response were combined into a coefficient of infection (CI) by multiplying the rust intensity by a constant assigned to various categories of host response $(28,38)$. The categories of host response (and associated constants) were infection type 0 to ; (constant $=0$ ), infection type 1 (constant = 0.2 ), infection type 2 (constant $=0.4$ ), infection type 3 (constant $=0.8$ ), and infection type 4 (constant $=1$ ). Coefficients of infection were averaged across replications for each line in each experiment.

For experiments in which leaf tip necrosis was observed, presence (+) or absence $(-)$ of leaf tip necrosis on flag leaves of the lines was recorded at the same time as rust intensity and host response. In order to postulate the presence of gene $L r 34$, frequency of positive observations was calculated across the 12 replications in which leaf tip necrosis was observed. Lines that expressed leaf tip necrosis in six or more of the replications were considered positive, and lines that expressed leaf tip necrosis in four or fewer replications were considered negative.

Growth chamber studies on adult plants. To determine which lines had adult-plant resistance and to postulate named adult-plant resistance genes by matching infection types, adult plants of 110 lines that were susceptible at the seedling stage were evaluated for infection type under controlled conditions. Five lines were not tested because seedlings were resistant to all races used, and seedlings of TW94315 died during vernalization. Sixtytwo lines that were hypothesized to have adult-plant resistance based on moderate resistance to moderate susceptibility in the field or postulated to have unknown genes in the seedling tests (39) were evaluated during the winter of 2000-2001. The remaining 48 lines were evaluated during the winter of 2001-2002. In both groups, seedlings were vernalized for 4 weeks in petri dishes at 4 to $6^{\circ} \mathrm{C}$ and then transplanted to $7.5-\mathrm{cm}$ square pots filled with potting mix (peat moss, vermiculite, perlite, Roxanna silt loam, and sand in a 6:4:2:3:3 ratio by volume, respectively). Plants were vernalized in growth chambers for an additional 2 weeks at $6^{\circ} \mathrm{C}$ followed by 1 week at $12 / 8^{\circ} \mathrm{C}$ day/night. After vernalization, plants were transplanted to $15-\mathrm{cm}$ diameter pots and grown at $20 / 15^{\circ} \mathrm{C}$ day/night in a greenhouse with supplemental light on a 14-h photoperiod. Plants were fertilized with Peters 20-20-20 NPK fertilizer and treated with insecticides for thrips and aphids as needed.

At Zadoks (40) growth stage 50 to 59 (beginning to completion of ear emergence), the adaxial surface of at least three flag leaves per pot were inoculated by spraying with fresh urediospores suspended in Soltrol 170 mineral oil (Chevron-Phillips Chemical Co., Houston, TX). Urediospores were produced on seedlings of susceptible cultivars as described previously (39). Each line was inoculated with only one race of $P$. triticina (MCRN, TLRT, TFRP, TDRN, or PNMT) depending on which race was most virulent on seedlings of the line. Adult plants of Thatcher isolines with genes $\operatorname{Lr} 12,13,34$, and 13, 34 (TcLr12, TcLr13, TcLr34, and TcLr13, 34, respectively), Sturdy ( $\operatorname{Lr} 12$, 34), Stephens (Lr13, 34), Auburn (Lr12+), and Collin $(\operatorname{Lr} 34+)$, and two susceptible cultivars (Thatcher and Morocco) were included as controls. After 18 to $24 \mathrm{~h}$ in a dew chamber at $20^{\circ} \mathrm{C}$, plants were incubated in a growth chamber at $22 / 18^{\circ} \mathrm{C}$ day/night with a 12-h photoperiod. This environment was selected as the most appropriate environment for the expression of $\operatorname{Lr} 12,13$, and 34. Infection types were recorded 16 to 18 days after inoculation when the susceptible controls showed a high infection type. Each line was tested three times.

Detection of Lr34 under controlled conditions. Because Lr34 had been detected in seedlings at $10^{\circ} \mathrm{C}$ and low light intensity (9) and at $15^{\circ} \mathrm{C}(7)$, the 62 lines that were most likely to have adult-plant resistance were tested at seedling stage under different temperatures and light intensities. Cultivars Morocco, TcLr12, TcLr13, TcLr34, TcLr13, 34, Caldwell (Lr12, 13+), Auburn, Knox (Lr12, 34), and Sturdy were included as controls. Races MCRN, TLRT, and TFRP were used to inoculate seedlings of all lines as described previously. After the dew period, seedlings were incubated in growth chambers at $10^{\circ} \mathrm{C}$ (12-h photoperiod at 58,125 lux), $15 / 10^{\circ} \mathrm{C}$ day/night (12-h photoperiod at 58,125 lux), or $22 / 18^{\circ} \mathrm{C}$ day/night (12-h photoperiod at 77,500 lux). Infection types were recorded 16 to 18 days after inoculation when the susceptible controls showed a high infection type. The experiment was done twice.

Because Singh and Gupta (33) reported that lines with $\operatorname{Lr} 34$ had a lower infection type on primary leaves of 13-day-old seedlings than on primary leaves of 8-day-old seedlings, 29 wheat lines that were suspected to have $L r 34$ were inoculated at 8 days and 13 days after planting. TcLr12, TcLr13, TcLr34, TcLr13, 34, Knox, Sturdy, Caldwell, and Thatcher were included as controls. Each line was inoculated with one race (MCRN, TFRP, or TLRT) that was most virulent on seedlings of the line (39). Plants were incubated in a growth chamber at $18 / 15^{\circ} \mathrm{C}$ day/night and $12-\mathrm{h}$ photoperiod at an intensity of 58,125 lux. Infection type was recorded on primary leaves 14 days after inoculation. The experiment was done twice.

Detection of $\mathbf{L r 1 3}$. Because Pretorius et al. (25) were able to detect $\operatorname{Lrl3}$ at the seedling stage, 10-day-old seedlings of the 116 lines were inoculated with the same two isolates of $P$. triticina (81-LCB-CH and 82-BHL-MD) and were incubated under similar conditions. Isolates were obtained from D. Long at the USDA-ARS Cereal Disease Laboratory in St. Paul, $\mathrm{MN}$. Inoculation and incubation in a dew chamber were as described previously. After the dew period, plants were incubated in growth chambers programmed to maintain 18.1 or $25.5^{\circ} \mathrm{C}$ and light intensity of 77,500 lux. Infection types were recorded 14 days after inoculation as described previously. The experiment was done twice.

To detect the presence of Lrl3 by progressive hybrid necrosis (a trait controlled by a gene, $\mathrm{Ne} 2 \mathrm{~m}$, that is tightly linked with Lr13), 45 wheat lines suspected to have 
Lrl3 were crossed to the Australian spring wheat cultivar, Spica, that was reported to have the complementary gene, $\mathrm{Nel}$, for progressive hybrid necrosis $(31,37)$. Seeds of Spica were obtained from J. Kolmer (USDA-ARS, Cereal Disease Laboratory, St. Paul, MN). Spica was used as the female parent in all crosses. Thatcher was included as a negative control, and TcLrl3 and $T c L r 13,34$ were included as positive controls. The $F_{1}$ seeds were dried and treated intermittently with $1 \%$ hydrogen peroxide to enhance germination. Nonvernalized seedlings were transplanted to $15-$ $\mathrm{cm}$-diameter pots filled with potting mix and grown in a greenhouse.

\section{RESULTS}

Field studies. During the 4-year study, leaf rust developed late in the season and not uniformly at all locations. However, disease pressure was sufficiently high in six of the 14 field experiments that were planted (Table 1). Nearly $29 \%$ of the lines were resistant $(\mathrm{CI}<10)$ in all six experiments, no line was susceptible $(\mathrm{CI}>40)$ in all six experiments, and only $30 \%$ of the lines were susceptible in one or more of the six experiments.

Six field experiments (12 replications) were suitable for evaluating the presence or absence of leaf tip necrosis (Table 1). Evaluations in the other experiments were confounded by stripe rust, drought stress, or leaf damage from windblown soil. Twenty-seven lines expressed leaf tip necrosis in six or more of the replications and were considered positive. Sabbe and M95*2883 expressed leaf tip necrosis in 11 of 12 replications and had the most consistent expression of this trait. Eightynine lines that expressed leaf tip necrosis in four or fewer of the replications were considered negative, and of these lines, 33 did not express leaf tip necrosis in any of the replications.

Growth chamber studies on adult plants. Of the 110 lines evaluated for adult-plant resistance in the growth chamber, 103 expressed some level of adultplant resistance (infection types less than 3) to a race that was virulent on seedlings (Table 1). Only seven lines did not express adult-plant resistance (infection type 3 or greater). Seedlings of TW94315 died during vernalization, and five lines were not tested because seedlings were resistant to all races used. The susceptible controls, Thatcher, Morocco, and Ernie, displayed a high infection type with all races (Table 2). The races tested produced a distinctive low infection type with prominent necrosis on TcLr12. Seventeen lines had a low infection type with prominent necrosis similar to that on TcLr12 and were postulated to have $L r 12$. All races produced a range of low infection type on TcLrl3 and TcLr34 in which the ; infection type did not predominate. However, all races produced a range of low infection type on $T c L r 13,34$,
Auburn, and Stephens in which the ; infection type did predominate. All races produced a ; infection type on Sturdy that matched the infection type of 40 lines. Excluding the 17 lines postulated to have Lr12, nearly $65 \%$ of the lines had a low infection type in which the ; infection type predominated, indicating that these lines likely had more than one gene for adultplant resistance. For lines postulated to have one known adult-plant resistance gene, an additional unidentified (+) gene was postulated if the infection type from the growth chamber study and/or the field leaf rust coefficient of infection was lower than expected for the known gene. No leaf tip necrosis was observed on any of the lines.

Detection of Lr34 under controlled conditions. Seedling tests at $10^{\circ} \mathrm{C}$ or $15 / 10^{\circ} \mathrm{C}$ did not provide useful information on the presence or absence of Lr34 because there was no clear difference between the positive and the negative controls (data not shown). Tests at $10^{\circ} \mathrm{C}$ resulted in a ; infection type on nearly all lines. More than $93 \%$ of the lines tested at $15 / 10^{\circ} \mathrm{C}$ showed lower infection types when compared with infection types obtained from tests at $22 / 18^{\circ} \mathrm{C}$. The infection type on the susceptible controls (Thatcher and Morocco) and the negative controls (TcLr12 and TcLr13) also showed a similar trend.

Differences between infection types produced on primary leaves of 8-day-old and 13-day-old seedlings of lines with Lr34 were too small and inconsistent to reliably postulate the presence of Lr34 (data not shown). Most of the tested lines had slightly lower infection types on primary leaves of 13-day-old seedlings than on 8-day-old seedlings.

Detection of Lr13. Seedling tests conducted at 25.5 and $18.1^{\circ} \mathrm{C}$ using appropriate pathogen isolates (virulent on $\operatorname{Lr} 13$ at $18.1^{\circ} \mathrm{C}$ but avirulent on $\operatorname{Lrl3}$ at $25.5^{\circ} \mathrm{C}$ ) were useful for postulating Lr13. Twentythree lines that showed high infection types at $18.1^{\circ} \mathrm{C}$ and low infection types at $25.5^{\circ} \mathrm{C}$ with one or both of the pathogen isolates were considered positive for $\mathrm{Lr} 13$ (Table 3). Twenty-one lines that showed high infection type at both 18.1 and $25.5^{\circ} \mathrm{C}$ with one or both pathogen isolates were considered negative for $\operatorname{Lr} 13$. The presence or absence of Lrl3 could not be determined in 72 lines that were resistant to both isolates at both temperatures (data not presented).

None of the $F_{1}$ plants obtained by crossing 45 lines with Spica showed progressive hybrid necrosis. The $F_{1}$ plants obtained by crossing TcLrl3 and TcLr13, 34 with Spica also did not show the symptom for hybrid necrosis, indicating that the Spica seeds were not the correct genotype. Therefore, no information was obtained for Lrl3 from tests for progressive hybrid necrosis.

\section{DISCUSSION}

Results of this study indicated that more than $90 \%$ of the wheat lines that were susceptible at the seedling stage had some level of adult-plant resistance. The high frequency of adult-plant resistance in soft red winter wheat lines suggests that methods used by wheat breeders to select lines have indirectly selected for adult-plant resistance to leaf rust. In several lines, such as NK Coker 9184, NK Coker 9663, and Jaypee, adult-plant resistance was incorporated even in the presence of effective seedling resistance during the years that selections were being made. Generally it has been assumed that selecting adult-plant resistance in the presence of effective seedling resistance would be difficult or impossible $(22,23)$. Breeders of soft red winter wheat have relied on field selections more than on seedling tests for selecting resistance to leaf rust, and perhaps adult-plant resistance genes have become linked to beneficial traits that are selected in field.

Genes $\operatorname{Lr} 12,13$, and 34 were identified in approximately 15,20 , and $23 \%$ of the lines, respectively, and these genes are important components of adult-plant resistance to leaf rust in contemporary soft red winter wheat cultivars and breeding lines. These genes have been reported in sources of leaf rust resistance used in soft red winter wheat breeding programs $(15,21,26)$ and in early cultivars of soft red winter wheat (27). Virulence for $\operatorname{Lrl} 2$ and 13 has been reported in North America $(17,20,33)$, making these genes less effective in the field. All lines postulated to have Lr13 alone and two lines postulated to have $\operatorname{Lr} 12$ alone were susceptible in the field at some locations, supporting previous reports $(16,18,20,33)$ that these genes do not provide adequate adult-plant resistance unless they are combined with other Lr genes.

Gene Lr34 alone did not provide adequate resistance in most lines. High susceptibility was observed with cultivars Sabbe $(\mathrm{CI}=98)$, Terra E218 (CI = 77.5), and Stine $488(\mathrm{CI}=70)$ to race TNRL in the field. The frequency of leaf tip necrosis was among the highest in Sabbe and Terra E218, and therefore, the presence of Lr34 is very likely. McIntosh et al. (21) and Kolmer (16) also have reported high levels of leaf rust on lines with $\operatorname{Lr} 34$ alone. The level of resistance conferred by Lr34 appears to depend on the interaction with other $L r$ genes as reported by Drijepondt et al. (4) and Singh (30). Race TNRL was virulent to all seedling resistance genes in Sabbe, and there were no seedling resistance genes in Terra E218 and Stine 488 (39).

Several lines likely have some combination of two or more genes; however, only eight lines were postulated to have a twoway combination among $\operatorname{Lr} 12,13$, and 34 . Over $40 \%$ of the lines were determined to have unidentified $(+)$ adult-plant resistance 
Table 1. Average coefficient of infection for leaf rust across years, locations, and races, frequency of leaf tip necrosis (LTN), infection type on flag leaves in growth chamber tests using the listed races of Puccinia triticina, and adult-plant resistance (APR) genes postulated for 116 contemporary soft red winter wheat lines

\begin{tabular}{|c|c|c|c|c|c|c|c|c|c|c|}
\hline \multirow[b]{4}{*}{ Line } & \multicolumn{7}{|c|}{ Coefficient of infection $^{a}$} & \multirow{2}{*}{\multicolumn{3}{|c|}{ Growth chamber }} \\
\hline & \multirow{2}{*}{\multicolumn{3}{|c|}{1999}} & \multirow{2}{*}{\multicolumn{2}{|c|}{$\begin{array}{c}2001 \\
\text { Kibler }\end{array}$}} & \multirow{3}{*}{$\begin{array}{c}2002 \\
\text { Marianna }\end{array}$} & \multirow[b]{3}{*}{$\mathbf{L T N}^{\mathbf{b}}$} & & & \\
\hline & & & & & & & & \multirow{2}{*}{\multicolumn{2}{|c|}{$\begin{array}{c}\text { Infection } \\
\text { type }^{\mathrm{c}}\end{array}$}} & \multirow[b]{2}{*}{ APR gene } \\
\hline & Keiser & Rohwer & Kibler & TNRL & MCRN & & & & & \\
\hline Agripro Foster & 27 & 4 & 69 & 3 & 85 & 0 & 0 & TFRP & $; 122+$ & + \\
\hline Agripro Hickory & 15 & 2 & 37 & 74 & 0 & 0 & 1 & MCRN & $; 1 \mathrm{~N}$ & 12 \\
\hline Agripro Mallard & 7 & 1 & 3 & 3 & 20 & 1 & 2 & TFRP & $; 12 \mathrm{~N}$ & $12+$ \\
\hline Agripro Marion & 0 & 0 & 0 & 16 & 2 & 0 & 9 & NT & $\mathrm{NT}^{\mathrm{d}}$ & 34 \\
\hline Agripro Mason & 0 & 0 & 1 & 6 & 1 & 0 & 0 & TLRT & 3 & None \\
\hline Agripro Patton & 6 & 0 & 4 & 3 & 6 & 0 & 0 & TFRP & $; 12 \mathrm{~N}$ & $12+$ \\
\hline Agripro Shelby & 21 & 1 & 18 & 0 & 2 & 2 & 10 & TFRP & $33-; 2$ & 34 \\
\hline Agripro Shiloh & 3 & 0 & 0 & 30 & 0 & 45 & 0 & TLRT & 3 & None \\
\hline AGS 2000 & 12 & 6 & 12 & 2 & 18 & 0 & 2 & TFRP & $; 12 \mathrm{~N}$ & $12+$ \\
\hline AP-D94-5282 & 0 & 1 & 0 & 0 & 0 & 0 & 4 & NT & NT & $\mathrm{ND}^{\mathrm{d}}$ \\
\hline AP-D95*8811-1 & 0 & 0 & 0 & 3 & 0 & 2 & 3 & TLRT & ; & + \\
\hline AP-D95*8811-2 & 0 & 0 & 0 & $\ldots^{d}$ & 0 & 0 & 0 & TLRT & $1 ; 22+$ & + \\
\hline AP-D95-7763 & 0 & 0 & 0 & 0 & 0 & 0 & 3 & PNMT & ; & + \\
\hline Armor 3235 & 23 & 40 & $\ldots$ & 28 & 20 & 0 & 9 & TFRP & ; & 13,34 \\
\hline AR584A-3-1 & 3 & 3 & 0 & 28 & 0 & 6 & 9 & TFRP & ; & $34+$ \\
\hline BL931167 & 0 & 0 & 0 & 12 & 0 & 1 & 1 & TLRT & $; 12-\mathrm{N}$ & $12+$ \\
\hline BL940026 & 0 & 0 & 1 & 26 & 0 & 4 & 4 & TFRP & ; & + \\
\hline Buckshots' DS9193 & 0 & 0 & 0 & 35 & 0 & 14 & 0 & TLRT & $; 122+\mathrm{N}$ & 12 \\
\hline Caldwell & 0 & 6 & 3 & 0 & 3 & 6 & 7 & TFRP & $; 0$ & $13,34+$ \\
\hline Cardinal & 7 & 12 & 32 & 55 & 37 & 1 & 4 & TFRP & $; 22+1$ & $13+$ \\
\hline Delta Grow 3300 & 1 & 0 & 1 & 14 & 0 & 0 & 2 & MCRN & $; 1 \mathrm{~N}$ & 12,13 \\
\hline Delta King $1551 W$ & 30 & 56 & 60 & 20 & 0 & 2 & 1 & MCRN & ;122+ & $13+$ \\
\hline Delta King 9027 & 6 & 1 & 2 & 1 & 0 & 1 & 8 & TFRP & $2+; 33-$ & 34 \\
\hline Delta King 9051 & 1 & 2 & 7 & 0 & 0 & 2 & 2 & TFRP & ; & + \\
\hline Delta King 9121 & 0 & 0 & 3 & 0 & 0 & 0 & 0 & TFRP & ; & + \\
\hline Dixie 2000 & 0 & 0 & 0 & 0 & 0 & 0 & 0 & TLRT & $; 1 \mathrm{~N}$ & $12+$ \\
\hline Dixie 911 & 4 & 1 & 0 & 23 & 2 & 6 & 8 & TFRP & $; 2+\mathrm{N}$ & 12,34 \\
\hline EK 103 & 30 & 4 & 36 & 6 & 0 & 0 & 0 & TFRP & ;3- & + \\
\hline EK 114 & 9 & 6 & 26 & 3 & 6 & 4 & 2 & TFRP & ;3-3 & + \\
\hline EK 156 & 1 & 4 & 13 & 4 & 0 & 2 & 3 & TFRL & $; 22+\mathrm{N}$ & $12+$ \\
\hline F322W & 9 & 1 & 37 & 3 & 4 & 0 & 1 & TFRP & $; 22+\mathrm{N}$ & $12+$ \\
\hline FFR 522W & 0 & 1 & 0 & 0 & 0 & 0 & 1 & TLRT & 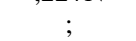 & + \\
\hline FFR 558W & 9 & 4 & 89 & 55 & 71 & 0 & 0 & TLRT & 21 & + \\
\hline Florida 302 & 30 & 50 & 55 & 12 & 70 & 3 & 0 & MCRN & $32+$ & None \\
\hline Florida 8868 & 0 & 0 & 3 & 47 & 0 & 1 & 1 & TLRT & ;3 & + \\
\hline G41332 & 6 & 6 & 0 & 35 & 0 & 1 & 4 & TFRP & $; 0$ & + \\
\hline G41333 & 9 & 9 & 12 & 38 & 0 & 0 & 3 & TFRL & ; & $13+$ \\
\hline G60232 & 1 & 1 & 0 & 1 & 0 & 1 & 4 & MCRN & $; 1$ & + \\
\hline GA881404E56 & 9 & 2 & 60 & 1 & 0 & 0 & 3 & TLRT & ; & + \\
\hline GA88622E51 & 0 & 0 & 0 & 0 & 0 & 1 & 8 & TFRP & ; & $34+$ \\
\hline GA90524E35 & 0 & $\ldots$ & 1 & 6 & 0 & 2 & 6 & TLRT & $; 1$ & 34 \\
\hline НT98-10033 & 4 & 11 & 33 & 26 & 3 & 0 & 2 & MCRL & $; 22+$ & $13+$ \\
\hline HT98-10291 & 1 & 3 & 40 & 18 & 0 & 0 & 1 & MCRN & ; & + \\
\hline IL91-15911 & 19 & 4 & 2.9 & 6 & 0 & 0 & 3 & TFRP & $; 2+$ & + \\
\hline IL94-2894 & 2 & 4 & 12 & 1 & 0 & 0 & 2 & TFRP & ; & $13+$ \\
\hline IL94-6727 & 1 & 7 & 45 & 1 & 3 & 0 & 0 & TFRP & ; & $13+$ \\
\hline Jackson & 21 & 2 & 31 & 16 & 1 & 3 & 7 & MCRL & $; 122+$ & 34 \\
\hline Jaypee & 9 & 4 & 6 & 25 & 0 & 0 & 10 & TFRP & 0 & $34+$ \\
\hline KY86C-127-3 & 8 & 9 & 26 & 2 & 35 & 1 & 0 & TFRL & ;22+ & + \\
\hline LA 87167D8-10-2 & 0 & 0 & 0 & 23 & 0 & 1 & 1 & TLRT & ;3-2 & + \\
\hline LA8513B1-7-B-1-4-2 & 0 & 0 & 14 & 4 & 0 & 32 & 0 & MCRN & $12 ; \mathrm{N}$ & $12+$ \\
\hline LA90144B16-3-2 & 0 & 0 & 0 & 0 & 0 & 0 & 0 & TLRT & $; 12-\mathrm{N}$ & $12+$ \\
\hline LA90412F14-1-4 & 0 & 0 & 0 & 0 & 0 & 0 & 0 & TLRT & $; 12-\mathrm{N}$ & $12+$ \\
\hline LA9070G45-3-3-1 & 3 & 0 & 0 & 0 & 6 & 0 & 1 & TLRT & $; 1 \mathrm{~N}$ & $12+$ \\
\hline M95*2883 & 9 & 15 & 23 & 50 & 38 & 2 & 11 & TFRP & $; 0$ & 13,34 \\
\hline M95*3330 & 9 & 12 & 70 & 43 & 71 & 7 & 3 & TFRP & ; & + \\
\hline M95*3349 & 3 & 11 & 78 & 28 & 78 & 9 & 0 & MCRN & $; 21+2+$ & + \\
\hline \multirow[t]{2}{*}{ Madison } & 10 & 4 & 67 & 12 & 58 & 6 & 3 & MCRN & 3 & None \\
\hline & & & & & & & & & \multicolumn{2}{|c|}{ (continued on next page) } \\
\hline
\end{tabular}

a Product of rust intensity and host response. Categories of host response (and associated constants) were infection type 0 to ; $(0)$, infection type 1 ( 0.2$)$, infection type 2 (0.4), infection type $3(0.8)$, and infection type 4 (1).

${ }^{\mathrm{b}}$ Frequency of leaf tip necrosis among 12 replications in the field. Frequencies $\geq 6$ were considered positive for $L r 34$, those $\leq 4$ were considered negative.

c $0=$ no macroscopic symptoms, ; = hypersensitive necrotic or chlorotic flecks, $1=$ small uredia surrounded by necrosis, $2=$ medium uredia surrounded by necrosis or chlorosis, $3=$ medium uredia without necrosis or chlorosis, $4=$ large uredia without necrosis or chlorosis, $+=$ uredia somewhat larger than normal, and $-=$ uredia somewhat smaller than normal. A range of infection types is indicated by listing more than one type, with the predominant one listed first. $\mathrm{N}=$ prominent necrosis.

${ }^{\mathrm{d}} \mathrm{NT}=$ not tested, $\mathrm{ND}=$ not determined, $\ldots=$ missing data. 
genes that were important components of adult-plant resistance to leaf rust in contemporary lines. These unidentified genes may be two-way or three-way combinations of $\operatorname{Lr} 12,13$, and 34 that could not be identified, other adult-plant genes, minor genes with additive effects, or modifying genes. Highly effective and durable resistance to leaf rust in bread wheat cultivars has been reported to result from the inter- action of Lr34 with other minor additive genes and was described as an "Lr34 complex" $(30,34,35,37)$. The high level of adult-plant resistance in cultivar Era was reported to result from the interaction between Lr13 with Lr34 and another unidentified adult-plant resistance gene $(13,24)$.

Adult-plant resistance was easily detected by evaluating infection types on flag leaves inoculated with a race virulent to seedlings. However, matching the infection type produced on a line with that on isolines with adult-plant resistance genes was only able to postulate the presence of $\operatorname{Lr} 12$. The distinctive low infection type with prominent necrosis produced on flag leaves of TcLr12 and 17 lines postulated to have $\operatorname{Lr} 12$ appeared to be a reliable and reproducible method for postulating $\mathrm{Lr} 12$ and was in agreement with the infection

Table 1. (continued from previous page)

\begin{tabular}{|c|c|c|c|c|c|c|c|c|c|c|}
\hline \multirow[b]{4}{*}{ Line } & \multicolumn{7}{|c|}{ Coefficient of infection $^{a}$} & \multirow{2}{*}{\multicolumn{3}{|c|}{ Growth chamber }} \\
\hline & \multirow{2}{*}{\multicolumn{3}{|c|}{1999}} & \multirow{2}{*}{\multicolumn{2}{|c|}{$\begin{array}{c}2001 \\
\text { Kibler }\end{array}$}} & \multirow{3}{*}{$\frac{2002}{\text { Marianna }}$} & \multirow[b]{3}{*}{$\mathbf{L T N}^{\mathbf{b}}$} & & & \\
\hline & & & & & & & & \multirow{2}{*}{\multicolumn{2}{|c|}{$\begin{array}{c}\text { Infection } \\
\text { type }^{c}\end{array}$}} & \multirow[b]{2}{*}{ APR gene } \\
\hline & Keiser & Rohwer & Kibler & TNRL & MCRN & & & & & \\
\hline MO94-317 & 7 & 11 & 82 & 77 & 55 & 9 & 4 & TFRP & ; & + \\
\hline NC94-7197 & 0 & 0 & 0 & 3 & 0 & 0 & 0 & NT & NT & ND \\
\hline NC95-25305 & 4 & 15 & 0 & 3 & 0 & 12 & 4 & MCRN & ; & + \\
\hline NC95-25707 & 0 & 0 & 9 & 6 & 0 & 4 & 1 & TLRT & $; 1 \mathrm{~N}$ & + \\
\hline NK Coker 9025 & 8 & 2 & 0 & 44 & 0 & 0 & 6 & TFRP & ; & $34+$ \\
\hline NK Coker 9152 & 0 & 0 & 3 & 4 & 0 & 0 & 2 & TDRL & ; & + \\
\hline NK Coker 9184 & 0 & 0 & 3 & 35 & 0 & 2 & 8 & TFRP & ; & $34+$ \\
\hline NK Coker 9543 & 3 & 3 & 25 & 0 & 0 & 0 & 1 & MCRN & ;3-2 & + \\
\hline NK Coker 9663 & 0 & 0 & 0 & 4 & 0 & 1 & 9 & TLRT & ;22+3- & 34 \\
\hline NK Coker 9704 & 4 & 3 & 6 & 0 & 0 & 0 & 6 & TFRP & $; 2 \mathrm{~N}$ & 12,34 \\
\hline NK Coker 9835 & 2 & 0 & 0 & 0 & 12 & 26 & 0 & TLRT & $1 ; 22+$ & + \\
\hline OH 536 & 3 & 4 & 1 & 0 & 0 & 0 & 0 & TFRP & 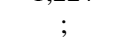 & + \\
\hline OH 552 & 1 & 7 & 25 & 0 & 0 & 1 & 8 & MCRL & ;123- & 13,34 \\
\hline OH 599 & 29 & 30 & 55 & 25 & 85 & 0 & 0 & TFRP & 43 & None \\
\hline OK91P648-41 & 0 & 1 & 20 & 6 & 0 & 0 & 0 & TFRP & ; & $13+$ \\
\hline P86364RA1-4-2-7 & 4 & 6 & 6 & 35 & 7 & 2 & 1 & TFRP & ; & $13+$ \\
\hline P88204RB1-2-1-6 & 6 & 6 & 24 & 1 & 0 & 0 & 0 & TFRP & 0 & + \\
\hline P92227C5-1-1 & 6 & 14 & 12 & 0 & 0 & 0 & 1 & TFRP & 0 & $13+$ \\
\hline Pioneer 2548 & 18 & 12 & 45 & 12 & 41 & 3 & 0 & MCRN & ;122+ & 13 \\
\hline Pioneer 2684 & 6 & 14 & 12 & 3 & 0 & 0 & 0 & TFRP & ;13- & + \\
\hline Pioneer 26R46 & 12 & 23 & 35 & 3 & 0 & 0 & 0 & MCRN & ; & + \\
\hline Pioneer 26R61 & 6 & 3 & 6 & 1 & 0 & 0 & 7 & TFRP & $; 0$ & $34+$ \\
\hline Pioneer XW672 & 4 & 6 & 24 & 0 & 4 & 0 & 1 & MCRN & ; & $13+$ \\
\hline Pioneer 26R24 & 9 & 4 & 1 & 8 & 0 & 0 & 4 & TFRP & $; 0$ & + \\
\hline Pocahontas & 15 & 4 & 18 & 6 & 47 & 1 & 2 & TLRT & $33+$ & None \\
\hline Quantum 708 & 1 & 16 & 45 & 20 & 0 & 1 & 0 & TFRP & 3 & None \\
\hline Roane & 14 & 0 & 40 & 25 & 45 & 1 & 8 & TFRP & $; 2$ & 34 \\
\hline Roberts & 2 & 4 & 20 & 0 & 0 & 1 & 9 & TFRP & ;3-2 & $34+$ \\
\hline Sabbe & 14 & 4 & 50 & 98 & 0 & 7 & 11 & TLRT & $2 ; 2+$ & 34 \\
\hline SC9412192 & 27 & 40 & 45 & 43 & 70 & 0 & 3 & MCRN & ; & + \\
\hline SC921285 & 0 & 16 & 30 & 44 & 0 & 1 & 3 & MCRN & 0 & + \\
\hline SC921299 & 0 & 11 & 26 & 3 & 1 & 0 & 2 & TFRP & 0 & + \\
\hline SS36803 & 23 & 11 & 13 & 0 & 0 & 0 & 6 & TFRP & $; 0$ & $34+$ \\
\hline SS550 & 15 & 3 & 3 & 3 & 85 & 0 & 1 & TFRP & ; & + \\
\hline Stine 455 & 30 & 19 & 56 & 1 & 36 & 0 & 1 & MCRN & ;12- & 13 \\
\hline Stine 488 & 14 & 4 & 70 & 0 & 41 & 1 & 6 & MCRN & $; 22+$ & 34 \\
\hline Stine 950455 & 70 & 47 & 72 & 0 & 35 & 4 & 3 & MCRN & ;12- & 13 \\
\hline $\mathrm{T} 104$ & 33 & 23 & 25 & 70 & 78 & 0 & 0 & MCRN & ;12-2+ & + \\
\hline T105 & 2 & 33 & 26 & 20 & 32 & 0 & 1 & MCRN & ;122+ & + \\
\hline T106 & 7 & 18 & 27 & 1 & 9 & 0 & 3 & MCRN & $; 12-\mathrm{N}$ & $12+$ \\
\hline T109 & 7 & 9 & 8 & 0 & 3 & 0 & 0 & TFRP & ; & + \\
\hline Terra E218 & 14 & 1 & 78 & 12 & 23 & 4 & 9 & MCRN & ;123- & 34 \\
\hline Terra SR204 & 7 & 4 & 85 & 20 & 46 & 3 & 3 & MCRN & $; 122+$ & 13 \\
\hline Terra SR216 & 2 & 1 & 1 & 49 & 1 & 2 & 2 & TFRP & ;23- & + \\
\hline Terral TV 8555 & 0 & 1 & 1 & 1 & 0 & 0 & 0 & TFRP & $; 122+$ & + \\
\hline Terral TV 8768 & 7 & 2 & 13 & 1 & 28 & 0 & 0 & NT & NT & ND \\
\hline Terral TV 8825 & 1 & 1 & 37 & 12 & 0 & 0 & 1 & TFRP & ; & + \\
\hline Terral TVX8670 & 6 & 8 & 6 & 0 & 0 & 1 & 0 & MCRN & ; & + \\
\hline TW94315 & 7 & 23 & 70 & 6 & 23 & 0 & 0 & NT & NT & 13 \\
\hline TX87-20 & 0 & 3 & 5 & 0 & 0 & 0 & 1 & PNMT & $; 1$ & + \\
\hline TX91-13 & 0 & 0 & 0 & 1 & 3 & 0 & 6 & PNMT & ; & 34 \\
\hline USG 3408 & 16 & 6 & 23 & 20 & 1 & 0 & 6 & TFRP & ; & 13,34 \\
\hline USG Exp 97-4 & 10 & 28 & 70 & 25 & 78 & 9 & 0 & MCRN & $; 1$ & + \\
\hline USG 3209 & 14 & 0 & 4 & 15 & 32 & 0 & 3 & MCRN & $; 23-$ & + \\
\hline VA96-54-326 & 5 & 4 & 4 & 3 & 38 & 0 & 2 & TFRP & ;3- & + \\
\hline VA97W-375 & 0 & 0 & 1 & 0 & 0 & 1 & 7 & NT & NT & 34 \\
\hline Wakefield & 21 & 4 & 63 & 0 & 44 & 2 & 2 & MCRN & $; 122+$ & 13 \\
\hline Wilfarm 488 & 23 & 4 & 78 & 20 & 78 & 3 & 4 & MCRN & $1 ; 22+$ & 13 \\
\hline
\end{tabular}


type described in McIntosh et al. (21). Even though all the races used in the adultplant experiments were avirulent on TcLr13 and TcLr34, the low infection types were not distinctive enough to be useful for postulating the presence of $\operatorname{Lr} 13$ or 34 .

Seedling tests conducted at 25.5 and $18.1^{\circ} \mathrm{C}$ using the two races virulent on Lrl3 at $18.1^{\circ} \mathrm{C}$ but avirulent on $\operatorname{Lrl3}$ at $25.5^{\circ} \mathrm{C}$ appeared to be definitive for postulating $\mathrm{Lr} 13$ as reported by Pretorius et al. (25). However, $62 \%$ of the lines were resistant to these races at both temperatures and could not be evaluated for $L$ r13. Additional races avirulent on $\operatorname{Lrl3}$ and with combinations of virulence to overcome epistatic effects of the other $L r$ resistance genes are needed to identify $L r 13$ in these lines. In retrospect, including TcLr13 in the set of isolines used in the previous seedling study (39) may have identified additional races avirulent to $L r 13$, and some of these races may have been useful for postulating Lrl3 in additional lines.

Compared with the other methods we used to detect $L r 34$, the presence of leaf tip necrosis in the field appeared to be the best method for postulating Lr34. Leaf tip necrosis has been reported as a reliable marker to detect the presence of $\operatorname{Lr} 34$ (30); however, its expression can be influenced by environment (6) and genetic background (32). Of the locations where leaf tip necrosis was evaluated, Kibler was the only irrigated location and had the most favorable environment for expression of leaf tip necrosis. Irrigation at Kibler likely alleviated drought stress and may have enhanced the expression of leaf tip necrosis. However, no line showed leaf tip necrosis $100 \%$ of the time, and some lines that were postulated not to have $L r 34$ expressed leaf tip necrosis in a few replications. Six of 12 replications with leaf tip necrosis appeared to be an appropriate threshold for postulating Lr34 because none of the lines expressed leaf tip necrosis in five replications, thus dividing the lines into two distinct groups. However, postulation of $\operatorname{Lr} 34$ based on leaf tip necrosis under these conditions should not be considered definitive. Multiple recordings of leaf rust intensity in the field may have been useful for determining slow rusting types of resistance to support the presence or absence of Lr34 that confers slow rusting. However, leaf rust developed late in the season and allowed a maximum of only two recordings. Seedling tests at low tem- peratures and light intensity were not useful for identifying $\operatorname{Lr} 34$.

It may have been useful to include lines known to have Lr34 as controls for evaluating leaf tip necrosis in the field. However, of the 137 lines listed as having Lr34 in the USDA-ARS Cereal Disease Laboratory database (27), none are soft red winter lines adapted to Arkansas. The lack of soft red winter lines and the preponderance of CIMMYT lines listed as having Lr34 may indicate that conditions are favorable for the expression of leaf tip necrosis where CIMMYT evaluates its lines and unfavorable where soft red winter lines are evaluated. Lines showed clear differences for leaf tip necrosis at CIMMYT's El Batan headquarters in Mexico, where nurseries were irrigated regularly and night temperatures after heading stage were much cooler than in Arkansas after heading stage (E. A. Milus, personal observation). The combination of optimal moisture for plant development and cool night temperatures may be required for consistent expression of leaf tip necrosis. Expression of resistance attributed to Lr34 generally is considered to be greater at lower temperature ranges (21), but no reports describing the effect of temperature on leaf tip necrosis were found.

The most reliable method for identifying combinations of adult-plant resistance genes was to identify them individually using the methods described above. For example, Dixie 911 was postulated to have Lr12 based on the distinctive infection type in the growth chamber test and Lr34 based on leaf tip necrosis in the field. Likewise, M95*2883 was postulated to have $\mathrm{Lrl3}$ based on the seedling test for Lrl3 and Lr34 based on leaf tip necrosis. This method identified two-way combinations among $\operatorname{Lr} 12,13$, and 34 in only eight of 103 lines with adult-plant resistance.

Matching infection types with controls believed to have combinations of adultplant resistance genes did not allow definitive identification of adult-plant resistance genes. One problem with the method was that, except for $T c L r 13,34$, the controls did not have a truly known combination of adult-plant resistance genes. For example, Sturdy was determined to have Lrl2 and 34 by genetic analysis (6), but the infection type on Sturdy was consistently a hypersensitive fleck that was lower than for other lines postulated to have LrI2 and 34 . Likewise, Auburn was reported to have
Lr12+ (D. Marshall, personal communication), but the infection type was similar to that on TcLr13, 34 (Table 2). A second problem with this method was that more than one combination of adult-plant resistance genes appeared to produce the same infection type. For example, of the lines observed to have a ;122+ infection type on flag leaves in the growth chamber test (Table 1), Pioneer 2548, Terra SR204, and Wakefield were postulated to have Lrl3 alone, Jackson and Terra E218 were postulated to have Lr34 alone, and T105 was postulated as + and did not have Lr34 or 13. Furthermore, these lines had the same infection type as TcLr13, 34. Therefore, matching infection types on the flag leaves was not useful for postulating genes $\operatorname{Lrl3}, 34$ or combinations of adultplant genes.

Caldwell was postulated to have $\operatorname{Lr} 12$, $13+$ (D. Marshall, personal communication); however, in this study it was postulated to have $\operatorname{Lr} 13,34+$. Caldwell had high infection type at $18.1^{\circ} \mathrm{C}$ and low infection type at $25.5^{\circ} \mathrm{C}$ with the pathogen isolates that were virulent on $\operatorname{Lrl3}$ at $18.1^{\circ} \mathrm{C}$ and avirulent on $\operatorname{Lrl} 3$ at $25.5^{\circ} \mathrm{C}$ and therefore was considered positive for Lr13. The frequency of leaf tip necrosis on Caldwell indicated the presence of Lr34. Moreover, the infection types produced on USG 3408, Armor 3235, and M95*2883, which were postulated to have the combination of Lrl3 and 34, were similar to that on Caldwell. Despite the absence of seedling $\mathrm{Lr}$ genes in Caldwell (39), the level of resistance in the field was higher compared with these lines. Therefore, it is likely that Caldwell had at least one adult-plant resistance gene in addition to $\operatorname{Lrl3}$ and 34 . Although $\operatorname{Lrl2}$ was not postulated in Caldwell based on infection type in growth chamber experiments in this study, Lr12 may be present because infection type was not useful for identifying genes in combinations.

This study clearly demonstrated the high frequency of adult-plant resistance and its value for protecting soft red winter wheat from leaf rust. However, none of the published methods that we used to postulate genes for adult-plant resistance give definitive results, and consequently, the genes postulated in this study should be interpreted as tentative. This study underscores the difficulty of postulating genes for adult-plant resistance. Currently, genetic studies are the most reliable methods for

Table 2. Infection type ${ }^{a}$ produced on flag leaves of controls by the three races of Puccinia triticina used in the growth chamber study

\begin{tabular}{lccccccccccc}
\hline Race & Thatcher & Morocco & Ernie & TcLr12 & TcLr13 & TcLr34 & TcLr13+34 & Auburn & Collin & Stephens & Sturdy \\
\hline MCRN & $33+$ & $33+$ & $33+$ & $; 12 N$ & $22+; 3-$ & $2 ; 2+3-$ & $; 122+$ & $; 122+3$ & $; 1$ & $; 12-$ & $;$ \\
TLRT & $33+$ & 4 & 3 & $; 12-\mathrm{N}$ & $2 ; 2+3-$ & $1 ; 22+$ & $; 122+$ & $; 122+$ & $; 1$ & $; 2+1$ & $;$ \\
TFRP & $33+$ & $33+$ & $3+4$ & $; 22 \mathrm{~N}$ & $22+;$ & $2 ; 3-$ & $; 122+$ & $; 122+3-$ & $; 12$ & $; 2$ & $;$ \\
\hline
\end{tabular}

a $0=$ no macroscopic symptoms, ; = hypersensitive necrotic or chlorotic flecks, $1=$ small uredia surrounded by necrosis, $2=$ medium uredia surrounded by necrosis or chlorosis, $3=$ medium uredia without necrosis or chlorosis, $4=$ large uredia without necrosis or chlorosis. $+=$ uredia somewhat larger than normal, and $-=$ uredia somewhat smaller than normal. A range of infection types is indicated by listing more than one type, with the predominant one listed first. $\mathrm{N}=$ prominent necrosis. 
determining the presence or absence of particular resistance genes, but genetic studies are laborious, expensive, and still require phenotypic evaluations. Molecular markers for adult-plant resistance genes may eventually facilitate postulation studies, but development of these markers

likely will require phenotypic characteristics similar to those used in this study.

\section{ACKNOWLEDGMENTS}

We thank David Long and Jim Kolmer, USDAARS, Cereal Disease Laboratory, for providing pathogen isolates, seeds of isolines, advice, and information, and Ravi Singh from CIMMYT for his

Table 3. Infection type ${ }^{a}$ produced by isolates of Puccinia triticina on primary leaves of controls and lines of soft red winter wheat at two temperatures to detect $L r 13$

\begin{tabular}{|c|c|c|c|c|c|}
\hline \multirow[b]{3}{*}{ Control/line } & \multicolumn{4}{|c|}{ P. triticina isolate ${ }^{b}$} & \multirow[b]{3}{*}{ Lr13 } \\
\hline & \multicolumn{2}{|c|}{ 82-BHL-MD } & \multicolumn{2}{|c|}{ 81-LCB-CH } & \\
\hline & $18.1^{\circ} \mathrm{C}$ & $25.5^{\circ} \mathrm{C}$ & ${ }_{18.1^{\circ} \mathrm{C}}$ & $25.5^{\circ} \mathrm{C}$ & \\
\hline Morocco (susceptible) & 4 & 4 & 4 & 4 & - \\
\hline Ernie (susceptible) & 3 & 4 & 4 & 4 & - \\
\hline Thatcher (susceptible) & $3+$ & $3+$ & $3+$ & $33+$ & - \\
\hline TcLr12 & 4 & 4 & $2+$ & $2+$ & - \\
\hline TcLr34 & 3 & 3 & 3 & 3 & - \\
\hline TcLrl3 & 3 & 2 & $3+$ & 2 & + \\
\hline TcLrl3+34 & 3 & $22+$ & $2+3$ & 2 & + \\
\hline Coastal $(13+)$ & 4 & ; & $32+$ & ; & + \\
\hline Hadden $(13+)$ & $; 12$ & ; & $33-1$ & ; & + \\
\hline Armor 3235 & $2+$ & $2+$ & 4 & $2+$ & + \\
\hline Caldwell & 4 & $; 12$ & 4 & $; 1$ & + \\
\hline Cardinal & 4 & $; 2$ & ; & $; 1$ & + \\
\hline NK Coker 9543 & $; 1$ & 4 & 4 & 4 & - \\
\hline NK Coker 9704 & 3 & 3 & ; & ; & - \\
\hline Delta Grow 3300 & 4 & ;22+ & 4 & $22+$ & + \\
\hline Delta King $1551 W$ & ; & $; 1$ & 4 & $22+$ & + \\
\hline Delta King 9027 & ;2 & $22+$ & 4 & 4 & - \\
\hline Delta King 9051 & $2+$ & 4 & 2 & 4 & - \\
\hline Delta King 9121 & $; 2+$ & 4 & $; 1$ & 4 & - \\
\hline Dixie 911 & $; 2$ & 4 & 4 & 4 & - \\
\hline EK 103 & $; 1$ & $; 1$ & 3 & 3 & - \\
\hline EK 114 & ; & $; 1$ & 4 & 4 & - \\
\hline EK 156 & 4 & 4 & 4 & 4 & - \\
\hline F322W & 4 & 4 & 4 & 4 & - \\
\hline G41332 & 4 & 4 & 4 & 4 & - \\
\hline G41333 & 4 & $; 2+$ & 4 & 2 & + \\
\hline HT98-10033 & ; & ; & 4 & $; 22+$ & + \\
\hline IL91-15911 & 4 & 4 & 4 & 4 & - \\
\hline IL94-2894 & ; & ; & 4 & 2 & + \\
\hline IL94-6727 & 4 & 2 & 4 & 2 & + \\
\hline M95*2883 & 4 & $2+$ & 3 & 3 & + \\
\hline M95*3330 & 4 & 4 & 4 & 4 & - \\
\hline OH 552 & ; & ; & 4 & ; & + \\
\hline OK91P648-41 & 4 & $; 12$ & $; 12+$ & ;1 & + \\
\hline P86364RA1-4-2-7 & ; & ; & 4 & 2 & + \\
\hline P92227C5-1-1 & 3 & $22+$ & 4 & 2 & + \\
\hline Pioneer 2548 & ; & $; 1$ & 4 & $22+$ & + \\
\hline Pioneer XW672 & ; & ; & 4 & 2 & + \\
\hline Roane & 4 & 4 & 4 & 4 & - \\
\hline Stine 455 & 3 & ; & 4 & $; 2$ & + \\
\hline Stine 488 & 4 & 4 & 4 & $3+$ & - \\
\hline Stine 950455 & ; & ; & 4 & $; 22+$ & + \\
\hline T104 & 4 & 4 & 4 & 4 & - \\
\hline T105 & 4 & 4 & 4 & $3+$ & - \\
\hline T106 & 4 & 4 & 4 & 4 & - \\
\hline Terra E218 & 4 & 4 & 4 & $3+$ & - \\
\hline Terra SR204 & 4 & 4 & 4 & $2+$ & + \\
\hline Terra SR216 & 4 & 4 & 4 & 4 & - \\
\hline TW94315 & $; 1$ & $; 12$ & 4 & $; 2+$ & + \\
\hline USG 3408 & ; & 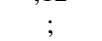 & 4 & $22+$ & + \\
\hline VA96-54-326 & 4 & 4 & 4 & 4 & - \\
\hline Wakefield & 4 & ; & 4 & ;2 & + \\
\hline Wilfarm 488 & $3+$ & $; 22+$ & 4 & $2+$ & + \\
\hline
\end{tabular}

a $0=$ no macroscopic symptoms, ; = hypersensitive necrotic or chlorotic flecks, $1=$ small uredia surrounded by necrosis, 2 = medium uredia surrounded by necrosis or chlorosis, $3=$ medium uredia without necrosis or chlorosis, $4=$ large uredia without necrosis or chlorosis, $+=$ uredia somewhat larger than normal, and $-=$ uredia somewhat smaller than normal. A range of infection types is indicated by listing more than one type, with the predominant one listed first.

${ }^{\mathrm{b}}$ Same $P$. triticina isolates used by Pretorius et al. (25).

${ }^{c}$ A line was considered positive (+) for $\operatorname{Lr} 13$ if at least one of the isolates produced a high infection type at $18.1^{\circ} \mathrm{C}$ and a low infection type at $25.5^{\circ} \mathrm{C}$. comments and suggestions. Technical support from the wheat pathology team of University of Arkansas and financial support from the Arkansas Wheat Promotion Board are gratefully appreciated.

\section{LITERATURE CITED}

1. Barcellos, A. L., Roelfs, A. P., and de MoraesFernandes, M. I. B. 2000. Inheritance of adult plant leaf rust resistance in the Brazilian wheat cultivar Toropi. Plant Dis. 84:90-93.

2. Bariana, H. S., and McIntosh, R. A. 1994 Characterization and origin of rust and powdery mildew resistance genes in VPM1 wheat. Euphytica 76:53-61.

3. Broers, L. H. M., and Jacobs, Th. 1989. The inheritance of host plant effect on latency period of wheat leaf rust in spring wheat. II Number of segregating factors and evidence for transgressive segregation in $\mathrm{F}_{3}$ and $\mathrm{F}_{5}$ generations. Euphytica 44:207-214.

4. Drijepondt, S. C., Pretorius, Z. A., and Rijkenberg, F. H. J. 1991. Expression of two wheat leaf rust resistance gene combinations involving Lr34. Plant Dis. 75:526-528.

5. Dyck, P. L. 1987. The association of a gene for leaf rust resistance with the chromosome 7D suppressor of stem rust resistance in common wheat. Genome 29:467-469.

6. Dyck, P. L. 1991. Genetics of adult plant leaf rust resistance and leaf tip necrosis in wheat. Crop Sci. 32:874-878.

7. Dyck, P. L., and Johnson, R. 1983. Temperature sensitivity of genes for resistance in wheat to Puccinia recondita. Can. J. Plant Pathol. 5:229-234.

8. Dyck, P. L., and Kerber, E. R. 1985. Resistance of the race specific type. Pages 469-500 in: The Cereal Rusts: Diseases, Distribution, Epidemiology and Control. A. P. Roelfs and W. R. Bushnell, eds. Academic Press, Orlando, FL.

9. Dyck, P. L., and Samborski, D. J. 1979. Adultplant leaf rust resistance in PI 250413, an introduction of common wheat. Can. J. Plant Sci. 59:329-332.

10. Dyck, P. L., and Samborski, D. J. 1982. The inheritance of resistance to Puccinia recondita in a group of common wheat cultivars. Can. J Genet. Cytol. 24:273-283.

11. Dyck, P. L., Samborski, D. J., and Anderson, R. G. 1966. Inheritance of adult plant leaf rust resistance derived from the common wheat varieties Exchange and Frontana. Can. J. Genet. Cytol. 8:665-691.

12. Dyck, P. L., and Sykes, E. E. 1994. Genetics of leaf rust resistance in three spelt wheats. Can. J. Plant Sci. 74:231-233.

13. Ezzahiri, B., and Roelfs, A. P. 1989. Inheritance and expression of adult plant resistance to leaf rust in Era wheat. Plant Dis. 73:549551.

14. German, S. E., and Kolmer, J. A. 1992. Effect of gene Lr34 in the enhancement of resistance to leaf rust of wheat. Theor. Appl. Genet. 84:97-105.

15. Kolmer, J. A. 1996. Genetics of resistance to wheat leaf rust. Annu. Rev. Phytopathol. 34:435-455.

16. Kolmer, J. A. 1997. Virulence in Puccinia recondita $\mathrm{f}$. $\mathrm{sp}$. tritici isolates from Canada to genes for adult-plant resistance to wheat leaf rust. Plant Dis. 81:267-271.

17. Kolmer, J. A. 1999. Physiologic specialization of Puccinia triticina in Canada in 1997. Plant Dis. 83:194-197.

18. Kolmer, J. A. 2002. Virulence phenotypes of Puccinia triticina in the South Atlantic states in 1999. Plant Dis. 86:288-291.

19. Kolmer, J. A., and Liu, J. Q. L. 1997. Physiologic specialization of Puccinia recondita $\mathrm{f}$. $\mathrm{sp}$. tritici in Canada in 1995. Can. J. Plant Pathol. 19:166-170.

20. Liu, J. Q., and Kolmer, J. A. 1997. Genetics of leaf rust resistance in Canadian spring wheats 'AC Domain' and 'AC Tabor'. Plant Dis. 
81:757-760.

21. McIntosh, R. A., Wellings, C. R., and Park, R. F. 1995. Wheat Rusts: An Atlas of Resistance Genes. Kluwer Academic Publishers, London.

22. Parlevliet, J. E. 1985. Resistance of the nonrace specific type. Pages 501-525 in: The Cereal Rusts: Diseases, Distribution, Epidemiology and Control. A. P. Roelfs and W. R. Bushnell, eds. Academic Press, Orlando, FL.

23. Parlevliet, J. E. 1988. Strategies for the utilization of partial resistance for the control of cereal rusts. Pages 48-62 in: Breeding Strategies for Resistance to the Rusts of Wheat. N. W. Simmonds and S. Rajaram, eds. CIMMYT, Mexico D.F.

24. Pretorius, Z. A., and Roelfs, A. P. 1996. The role of $\operatorname{Lr} 10, \mathrm{Lr} 13$, and $\operatorname{Lr} 34$ in the expression of adult-plant resistance to leaf rust in the wheat cultivar Era. Plant Dis. 80:199-202.

25. Pretorius, Z. A., Wilcoxson, R. D., Long, D. L., and Schafer, J. F. 1984. Detecting wheat leaf rust resistance gene $\mathrm{Lr} 13$ in seedlings. Plant Dis. 68:585-586.

26. Roelfs, A. P. 1988. Resistance to leaf and stem rust in wheat. Pages 10-22 in: Breeding Strategies for Resistance to the Rusts of Wheat. N. W. Simmonds and S. Rajaram, eds. CIMMYT,
Mexico D.F.

27. Roelfs, A. P., Hughes, M. E., and Long, D. L. 2000. Rust resistance genes in wheat lines and cultivars. U.S. Dep. Agric. Res. Serv. Cereal Dis. Lab. Online, Publication CDL-EP \# 006. Accessed November 7, 2002.

28. Roelfs, A. P., Singh, R. P., and Saari, E. E. 1992. Rust Diseases of Wheat: Concepts and Methods of Disease Management. CIMMYT, Mexico D.F.

29. Rubiales, D., and Niks, R. E. 1995. Characterization of $L r 34$, a major gene conferring nonhypersensitive resistance to wheat leaf rust. Plant Dis. 79:1208-1212.

30. Singh, R. P. 1992. Association between Lr34 for leaf rust resistance and leaf tip necrosis in wheat. Crop Sci. 32:874-878.

31. Singh, R. P. 1993. Resistance to leaf rust in 26 Mexican wheat cultivars. Crop Sci. 33:633637.

32. Singh, R. P., Chen, W. Q., and He, Z. H. 1999. Leaf rust resistance of spring, facultative, and winter wheat cultivars from China. Plant Dis. 83:644-651.

33. Singh, R. P., and Gupta, A. K. 1992. Expression of wheat leaf rust resistance gene Lr34 in seedlings and adult plants. Plant Dis. 76:489-491.
34. Singh, R. P., and Huerta-Espino, J. 1995 Inheritance of seedling and adult plant resistance to leaf rust in wheat cultivars 'Ciano 79' and 'Papago 86'. Plant Dis. 79:35-38.

35. Singh, R. P., and Huerta-Espino, J. 1997. Effect of leaf rust resistance on grain yield and agronomic traits of spring wheat. Crop Sci. 37:390-395.

36. Singh, R. P., Mujeeb-Kazi, A., and HuertaEspino, J. 1998. Lr46: A gene conferring slowrusting resistance to leaf rust in wheat. Phytopathology 88:890-894.

37. Singh, R. P., and Rajaram, S. 1991. Resistance to Puccinia recondita f. sp. tritici in $50 \mathrm{Mexi}-$ can bread wheat cultivars. Crop Sci. 3:1472 1479.

38. Stakman, E. C., Stewart, D. M., and Loegering, W. Q. 1962. Identification of physiological races Puccinia graminis var. tritici. U.S Dep. Agric. Agric. Res. Serv. Bull. E617 (Revised 1962)

39. Wamishe, Y. A., and Milus, E. A. 2004. Seedling resistance genes to leaf rust in soft red winter wheat. Plant Dis. 88:136-146.

40. Zadoks, J. C., Chang, T. T., and Konzak, C. F. 1974. A decimal code for the growth stages of cereals. Weed Res. 14:415-421. 